\title{
Keterampilan Konseling Keluarga Berencana Mahasiswa D3 Kebidanan Melalui Kuliah Daring Dimasa Pandemi Covid 19
}

\author{
Wayan Sugandini ${ }^{*}$, Luh Mertasar ${ }^{2}$ iD \\ 1,2 Jurusan Olahraga dan Kesehatan, Universitas Pendidikan Ganesha, Singaraja, Indonesia \\ *Corresponding author: wayan.sugandini@undiksha.ac.id
}

\begin{abstract}
Abstrak
Hasil belajar konseling mahasiswa belum mencapai nilai standar kelulusan dalam melaksanakan kompetensinya Tujuan penelitian untuk mengetahui kemampuan mahasiswa menerima pembelajaran Konseling Keluarga Berencana (KB) melalui perkuliahan dalam jaringan khususnya dalam melaksanakan konseling. Jenis penelitian deskriftif kuantitatif. Subjek penelitiannya adalah mahasiswa berjumlah 42 orang. Pengumpulan data dengan observasi menggunakan instrumen Cheklist, melalui evaluasi individu yang dilaksanakan secara Daring. Analisa data dengan analisis deskriptif kuantitatif. Hasil analisa menunjukkan bahwa hasil evaluasi keterampilan melakukan konseling Keluarga Berencana berada pada katagori Baik sampai sangat baik, semua mahasiswa yang mengikuti evaluasi individu mendapat skor lulus. Kesimpulannya bahwa keterampilan melakukan konseling mahasiswa D3 Kebidanan melalui kuliah Daring di masa pandemic Covid-19 baik dan semua mahasiswa memperoleh skor lulus. Jadi perkuliahan konseling keluarga berencana dapat diterima dengan baik dan tidak menemui hambatan yang berarti.
\end{abstract}

Kata kunci: Konseling, Keluarga Berencana, Daring

\section{Abstract}

The purpose of the research is to find out the ability of students to receive learning Family Planning Counseling (KB) through online lectures, especially in carrying out counseling. For some periods there are still students who have not been able to achieve the standard of graduation in conducting Family Planning counseling even though the lecture is carried out face-to-face, what if the lecture is done online. Types of quantitative deriftive research, the study subjects numbered 42 people. Data collection by observation using Cheklist instruments, through individual evaluations conducted online. Data analysis with descriptive quantitative analysis. The results of the analysis showed that the results of the evaluation of skills to conduct Family Planning counseling were in the category Of Good to very good, all students who participated in the evaluation of individuals got a pass score. The conclusion is that the skills of counseling students of D3 Midwifery Ganesha Education University through online lectures during the Covid-19 pandemic are good and all students get a graduation score. So family planning counseling lectures are well received and do not encounter any significant obstacles.

Keywords: Counseling, Family Planning, Online lectures

$\begin{array}{ll}\text { History: } & \\ \text { Received } & : 16 \text { Januari } 2021 \\ \text { Revised } & : 25 \text { Januari } 2021 \\ \text { Accepted } & : 18 \text { Februari } 2021 \\ \text { Published } & : 25 \text { Maret } 2021\end{array}$

Publisher: Undiksha Press

Licensed: This work is licensed under a Creative Commons Attribution 4.0 License (c) () ()

\section{Pendahuluan}

Pedidikan Diploma III Kebidanan merupakan pendidikan menghasilkan Bidan Pelaksana dengan gelar Ahli Madya Kebidanan yang diharapkan dapat membantu permasalahan yang terjadi di masyarakat (Winarni et al., 2014). Sesuai dengan wewenang bidan yang tercantum dalam PMK 1464 bidan berwenang memberikan pelayanan kesehatan reproduksi perempuan dan keluarga berencana, maka mata kuliah kesehatan Reproduksi dan Keluarga berencana termasuk salah satu mata kuliah inti pada mahasiswa D3 Kebidanan 
(Astuti et al., 2018). Pentingnya mata kuliah tersebut karena Program Keluarga Berencana (KB) adalah berkontribusi dalam menurunkan kematian ibu, pertumbuhan penduduk dan tingkat fertilitas dengan mengatasi kebutuhan $\mathrm{KB}$ yang tidak terpenuhi, menghilangkan kendala akses, dan meningkatkan kualitas pelayanan dalam menyediakan metode kontrasepsi modern yang digunakan secara sukarela oleh perempuan dan laki-laki di Indonesia. Salah satu peran dan fungsi bidan adalah sebagai pelaksana dalam pelayanan Keluarga Berencana, yaitu membantu calon akseptor menentukan pilihan yang tepat sehingga pilihannya sesuai dengan kondisi klien melalui konseling, dimana diwajibkan oleh BKKBN sebelum diputuskan penggunaan alat kontrasepsi calon akseptor harus dilakukan konseling (Astuti et al., 2018). Pelaksanaan konseling kepada calon akseptor BKKBN menerapkan beberapa langkah konseling. Agar para lulusan siap melaksanakan peran dan fungsinya sebagai pelaksana yaitu membantu klien menentukan pilihan yang tepat sehingga tidak menjadi permasalahan di kemudian hari, maka dalam pembelajaran dibutuhkan pembelajaran yang sesuai yang memberikan tantangan kepada peserta didik untuk belajar menjadi bidan yang dapat melakukan konseling dengan efisien dan efektif.

Namun, sejak pandemi covid19 melanda Dunia dan Indonesia, Menteri Pendidikan dan Kebudayaan Dikti mengeluarkan surat edaran No.1 tahun 2020, yang berisikan intruksi untuk melakukan pembelajaran secara Daring, hal ini tentu menimbulkan dampak positif maupun negatif dalam pelaksanaan perkuliahan. Hasil belajar konseling mahasiswa Diploma 3 Kebidanan Undiksha pada tahun 2019 menujukkan bahwa dari 80 mahasiswa yang mengikuti ujian pelaksanaan konselimg Keluarga Berencana, terdapat 32\% peserta harus mengikuti remidi karena belum mencapai nilai standar kelulusan dalam melaksanakan kompetensinya yaitu melaksanakan konseling Keluarga Berencana (Laporan Akademik. 2019). Pada tahun 2019 perkuliahan masih dilaksanakan dengan tatap muka langsung, sehingga semua proses pembelajaran dapat dilalui sebagaimana mestinya, namun masih terdapat mahasiswa yang harus mengulang ujian pelaksanaan konseling. Banyak kendala dalam pelaksanaan pembelajaran seperti jaringan internet yang kurang baik karena wilayah tempat tinggal tidak semua peserta didik berasal dari daerah perkotaan bahkan ada yang berasal dari luar provinsi sehingga masalahnya yang paling dirasakan adalah terganggunya jaringan internet. Mahasiswa lebih senang jika perkuliahan dilakukan secara tatap muka dari pada Daring (Fitriyani et al., 2020; Pakpahan \& Fitriani, 2020). Problematika yang dialami oleh siswa belajar Daring adalah sangat beragam baik itu dari peserta didik, guru maupun orang tua yang meliputi penguasaan IT, akses jaringan internet, keaktipan dalam mengikuti pembelajaran serta keterbatasan fasilitas (Asmuni, 2020; Harahap et al., 2021) .

Dalam pelaksanaan pembelajaran laboratorium yang dilaksanakan secara Daring untuk mencapai hasil yang optimal, dosen memberikan penuntun belajar dan cheklist konseling keluarga berencana, juga memberikan contoh konseling berupa vidio, memberikan tugas membuat skenario konseling serta membuat vidio pelaksanaan konseling oleh mahasiswa. Konseling keluarga berencana bertujuan untuk membantu calon akseptor memilih alat kontrasepsi yang sesuai, serta membantu akseptor yang memiliki masalah terkait dengan alat kontrasepsi yang digunakan untuk mengatasi masalah yang dihadapi (Sudarti \& Prasetyaningtyas, 2011; Sukarni et al., 2020). Melihat pentingnya konseling tersebut maka sangat dibutuhkan konselor yang dapat melakukan konseling dengan baik sehingga calon akseptor dan akseptor keluarga berencana mendapat layanan yang baik (Noviani, 2021). Setelah lulus dari pendidikan D3 Kebidanan agar mahasiswa dapat melakukan konseling dengan baik maka mereka harus belajar secara sungguh-sungguh dan diberikan pengalaman belajar secara komprehensif melakukan konseling keluarga berencana. Apabila pembelajaran yang diperoleh tidak optimal maka mereka tidak akan siap melakukan konseling setelah bertugas di tatanan nyata sehingga konseling yang dilakukan kurang optimal. 
Temuan penelitian ini diperkuat dengan penelitian yang menyatakan kualitas pelayanan konseling akan memperoleh penilaian baik, apabila karakteristik akseptor memenuhi kriteria usia yang muda, jumlah anak yang ideal (1-2 anak), pendidikan yang tinggi, pengetahuan yang baik, dan mendapat dukungan dari suami, sedangkan dari karakteristik bidan diantaranya memiliki pendidikan terakhir Bidan yang lebih tinggi, lama bekerja diatas 10 tahun, bidan pernah pelatihan. Faktor dominan yang mempengaruhi kualitas pelayanan konseling adalah pengetahuan akseptor (Noviani, 2021). Jika demikian adanya maka program mata kuliah kesehatan Reproduksi dan Keluarga berencana untuk menciptakan sumber daya manusia yang memiliki keterampiran konseling. Berdasarkan hal tersebut dilakukan penelitian keterampilan konseling keluarga berencana mahasiswa d3 kebidanan melalui kuliah daring dimasa pandemi covid 19.

\section{Metode}

Penelitian ini berjenis penelitian deskriftif kuantitatif dengan observasi yang bertujuan untuk menggambarkan hasil belajar konseling Keluarga Berencana pada Mahasiswa selama mengikuti pembelajaran dengan system Daring. Subjek penelitiannya adalah mahasiswa semester IV Prodi Kebidanan Fakultas Olahraga dan Kesehatan Universitas Pendidikan Ganesha. Pada Tahun Akdemik 2019/2020 terdapat 4 (empat) kelas, semester IV, yaitu kelas A, B, C dan kelas D. Untuk menentukan kelas yang dilakukan pembelajaran dengan role playing dilakukan randomisasi. Setelah dilakukan acak sederhana yang keluar menjadi sampel adalah kelas B dan Kelas C dengan jumlah mahasiswa 42 orang. Variabel yang akan diukur dalam penelitian ini adalah keterampilan mahasiswa melakukan konseling Keluarga Berencana. Data dikumpulkan melalui pengamatan menggunakan cheklist penilaian yang sudah tersedia, nilai standar lulus adalah 73 dengan katagori B. Data diambil pada saat dilakukan evaluasi individu pada akhir perkuliahan kesehatan reproduksi dan keluarga berencana, mahasiswa melakukan konseling menggunakan skenario yang telah ditentukan. Hipotesis yang ditegakkan adalah Keterampilan Konseling Keluarga Berencana D3 Kebidanan Melalui Kuliah Daring pada masa Pandemi Covid 19 Berada pada kategori Baik. Analisa data menggunakan analisis deskriftif kuantitatif.

\section{Hasil dan Pembahasan}

Dibawah ini adalah data nilai dari 42 orang peserta didik saat melakukan konseling keluarga berencana melalui perkuliahan Daring.

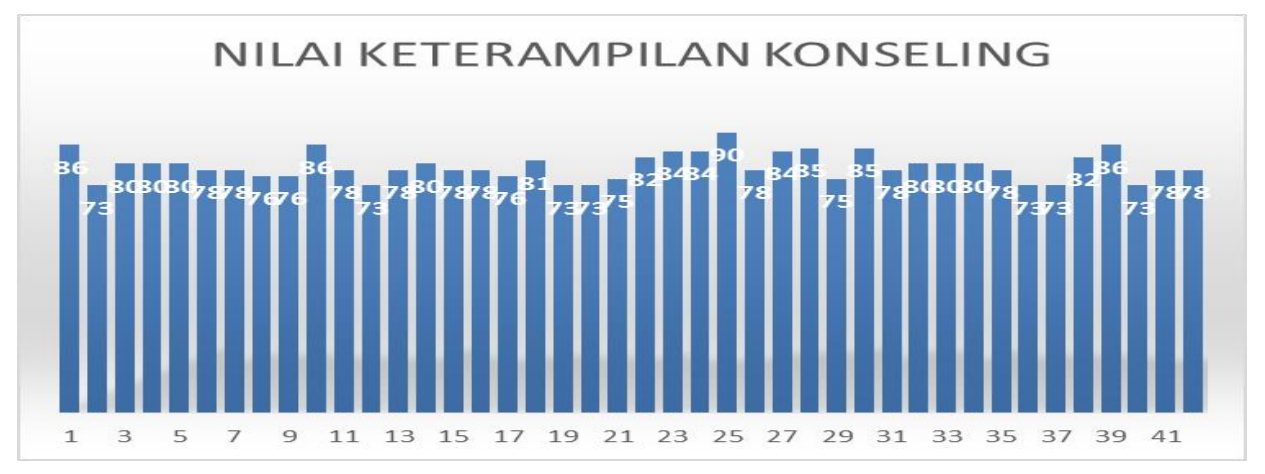

Gambar 1. Nilai Konseling Keluarga Berencana Melalui Perkuliahan Daring

Dengan memperhatikan Gambar 1 nilai rata peserta didik sudah melampaui skor batas lulus nilai keterampilan melakukan konseling keluarga berencana dengan langkah satu tuju. 
Tabel 1. Distribusi Nilai Konseling dari 42 Mahasiswa Semester IV

\begin{tabular}{cccc}
\hline No & Skala Presentil & Kategori & Frekuensi \\
\hline 1 & 14,3 & A & $85-100$ \\
2 & 14,3 & A- & $81-84$ \\
3 & 42,8 & B & $77-80$ \\
4 & 28,6 & B & $73-76$ \\
\hline Jumlah & $\mathbf{1 0 0}$ & & $\mathbf{4 2}$ \\
\hline
\end{tabular}

\section{Pembahasan}

Berdasarkan hasil penelitian tersebut, perkuliahan konseling keluarga berencana melalui Daring pada semester IV Diploma3 Kebidanan berjalan cukup efektif, hal ini dapat dilihat dari perolehan skor nilai mahasiswa melalui evaluasi individu sebagian besar berada diatas nilai standar kelulusan dalam melaksanakan keterampilan, meskipun masih terdapat sebagian kecil mahasiswa mendapat skor nilai batas lulus yaitu perolehan 73. Dari perolehan nilai konseling keluarga berencana diatas terlihat bahwa perolehan nilai terbanyak pada katagori baik yaitu nilai $\mathrm{B}(26,8 \%)$, nilai $\mathrm{B}^{+} 42,8 \%$ dimana masih banyak juga mahasiswa yang memperoleh nilai sangat baik diantaranya $A^{-}(14,3 \%)$ dan $A^{+}(14,3 \%)$. Hal ini menunjukkan bahwa mahasiswa dapat memahami pelaksanaan konseling dengan baik dan bahkan sangat baik melalui belajar melalui Daring, walaupun terdapat sebagian kecil mahasiswa yang memperoleh nilai standar minimal. Ini berarti bahwa semua mahasiswa yang mengikuti evaluasi konseling keluarga berencana bisa lulus walaupun mengikuti kuliah Daring.

Mahasiswa dapat melakukan konseling dengan baik karena mereka sudah memahami teori konseling itu sendiri dan memahami tentang alat kontrasepsi dengan baik. Banyak hal yang menyebabkan hasil belajar mahasiswa diantaranya, ketekutan, cara belajar, ketertarikan terhadap mata kuliah, cara penyampaian dosen, sarana belajar dan masih banyak fakor lain yang dapat mempengaruhi. Pembelajaran Daring sebenarnya sudah ada sejak beberapa tahun terakhir namun lebih sering digunakan semenjak pandemi covid-19, pembelajaran ini dipilih untuk memutus mata rantai penyebaran covid-19 (Putria, 2020). Dengan pembelajaran Daring mahasiswa merasa leluasa karena mereka dapat belajar dimana saja tidak terkekang oleh situasi yang formal, sehingga mereka dapat mengeksflorasi dengan caranya sendiri memberi makna dan arti dari materi yang diterima saat dosen memberikan penjelasan, disamping saat ini banyak terdapat materi perkuliahan yang dengan mudah mereka akses melalui internet (Asmuni, 2020). Khusus untuk keterampilan melaksanakan konseling KB banyak terdapat video tentang pelaksanaanya secara detail di Youtube sehingga dengan mudah mereka dapat mempelajari langkah demi langkah pelaksanaan konseling selanjutnya mereka hanya memadankan dengan materi, acuan pelaksanaan konseling yang diberikan oleh dosen. Perkuliahan Daring lebih diminati oleh mahasiswa karena mereka leluasa belajar dengan gayanya sendiri

Belajar konseling keluarga berencana merupakan pelajaran yang sangat menantang, karena mahasiswa dituntut dapat melakukan dengan baik kepada konseling, dengan tujuan agar konseli dapat menentukan pilihan sesuai dengan kondisinya sehingga tidak terjadi kegagalan maupun drop out saat menjadi akseptor yang akan berdampak kepada kehamilan yang tidak diinginkan (Rohimah, 2018). Pelaksanaan konseling keluarga berencana oleh BKKBN (2018) diterapkan menggunakan langkah satu tuju, Langkah tersebut dapat digunakan sebagai pegangan oleh konselor dalam melaksanakan konseling. Satu tuju merupakan singkatan tahapan pelaksanaan konseling sehingga mereka dapat dengan mudah mengingat setiap tahap yang akan dilaksanakan. Sebelum memutuskan memilih salah satu alat kontrasepsi calon akseptor keluarga berencana wajib diberi konseling, dengan tujuannya 
adalah agar calon akseptor dapat menentukan pilihan sesuai dengan kondisinya, karena masing-masing alat kontrasepsi memiliki indikasi kontra dan setiap individu mempunyai penyesuaian diri yang berbeda terhadap masing-masing alat kontrasepsi.

Pada materi kuliah konseling keluarga berencana, bertujuan agar dapat menjadi konselor yang baik serta apa yang harus mereka lakukan agar konseli mau menyampaiakan keinginan dan kondisinya secara jujur, selanjutnya materi tersebut dipraktikan dengan baik dalam kegiatan konseling (Lutfi et al., 2021). Belajar konseling mahasiswa dilakukan di rumah. Mahasiswa mengakui bahwa mereka melibatkan orang rumah sebagai konseling dengan belajar bermain peran dan bahkan ada yang belajar bersama temannya yang rumahnya berdekatan namun tetap menjalakan protocol kesehatan dengan menggunakan masker, menjaga jarak dan selalu mencuci tangan. Mahasiswa berinteraksi saling mengevaluasi satu sama lain dengan menggunakan daftar tilik serta membuat skenario terlebih dahulu sesuai dengan himbauan dosen, hal tersebut menunjukkan bahwa mahasiswa melakukan konseling keluarga berencana dengan baik. Konseling kelompok dengan teman sebaya, dimana hasilnya menunjukkan siswa mampu mengatasi permasalahan interaksi sosial dengan orang lain dan mampu membantu teman sebaya dalam kelompoknya (Setiawan, 2019).

Temuan penelitian diperkuat dengan temuan sebelumnya yang menyatakan terdapat hubungan pemberian konseling terhadap kepesertaan KB pasca salin (Abbas et al., 2017). Melalui konseling yang dilakukan oleh bidan setelah melaksanakan pelatihan calon akseptor memutuskan menggunakan alat kontrasepsi (Astuti, 2016; Ningsih, 2021). Dengan demikian sangat perlu menyiapkan peserta didik siap menjadi konselor yang efektif sehingga mereka bisa mengarahkan calon akseptor memilih alat kontrasepsi yang sesuai dengan kondisi masing-masing, sehingga tidak akan terjadi masalah yang berarti selama akseptor menggunakan alat kontrasepsi. Konseling keluarga berencana yang dilakukan kepada calon akseptor selain membantu memilih kontrasepsi yang tepat juga sangat mempengaruhi konseli sebagai calon akseptor mengambil keputusan untuk menggunakan atau tidak menggunakan alat kontrasepsi.

Sebagai pelayan kesehatan sangat penting memberikan penjelasan melalui konseling yang benar-benar dapat membantu menentukan pilihan yang tepat untuk dirinya sendiri. Maka dari itu sangat dibutuhkan konselor yang handal, sehingga tidak terkesan hanya melakukan konseling sekedarnya saja hanya untuk memenuhi prosedur pelayanan. Perbedaannya dengan penelitian ini adalah pada sasaran konselingnya yaitu konseling yang dilakukan pada individu bukan pada kelompok. Melalui pembelajaran tersebut peserta didik akan memperoleh pengalaman bagaimana melakukan hubungan sosial dengan orang lain, hal ini akan menjadi pegangan bagi dirinya.

\section{Simpulan}

Dalam penelitian ini dapat disimpulkan bahwa keterampilan konseling keluarga berencana melalui perkuliahan Daring pada masa pandemic Covid-19 tidak mempengaruhi capaian hasil belajar mahasiswa bahkan seluruh mahasiswa yang mengikuti evaluasi keterampilan dinyatakan meperoleh skor lulus.

\section{Daftar Rujukan}

Abbas, M., Hadijono, S., \& Emilia, O. (2017). Pengaruh Konseling saat Persalinan terhadap Kepesertaan Keluarga Berencana Pasca Salin di Kabupaten Kolaka. Jurnal Kesehatan Reproduksi, 4(1), 127-134. https://doi.org/10.22146/jkr.35425.

Asmuni, A. (2020). Problematika Pembelajaran Daring di Masa Pandemi Covid-19 dan Solusi Pemecahannya. Jurnal Paedagogy, 7(4), 281. https://doi.org/10.33394/jp.v7i4.2941. 
Astuti. (2016). Hubungan konseling terhadap pengambilan keputusan kesertaan keluarga berencana dalam perspektif HAM di kota yogyakarta. 12(1).

Astuti, L. P., Prasida, D. W., \& Wardhani, P. K. (2018). Peran dan Fungsi Bidan Dalam Pelaksanaan Informed Consent Pada Kegawatan Daruratan Obstetri Di Puskesmas. Jurnal Kebidanan, 9(02), 101. https://doi.org/10.35872/jurkeb.v9i02.313.

Fitriyani, Y., Fauzi, I., \& Sari, M. Z. (2020). Motivasi Belajar Mahasiswa Pada Pembelajaran Daring Selama Pandemik Covid-19. Profesi Pendidikan Dasar, 7(1), 121-132. https://doi.org/10.23917/ppd.v7i1.10973.

Harahap, S. A., Dimyati, D., \& Purwanta, E. (2021). Problematika Pembelajaran Daring dan Luring Anak Usia Dini bagi Guru dan Orang tua di Masa Pandemi Covid 19. Jurnal Obsesi: Jurnal Pendidikan Anak Usia Dini, 5(2), 1825-1836. https://doi.org/10.31004/obsesi.v5i2.1013.

Lutfi, M., Selmi, A., Dwi, A., \& Rusman, P. (2021). Effectivennes of the Implementation of Adolescent Family Development Programs ( BKR ) in the Departement of Population Cont. Jurnal Manusia Dan Kesehatan, 4(1), 10-23. https://doi.org/10.31850/makes.v4i1.361.

Ningsih, D. A. (2021). Faktor Yang Berhubungan Dengan Pemilihan Kb Mkjp. Jurnal Kesehatan Mercusuar, 4(1), 17-31. https://doi.org/10.36984/jkm.v4i1.160.

Noviani, A. (2021). Analysis Of Factors Affecting The Quality Of Counseling Service Long Term Contraception Method In Puskesmas Serengan Region, Surakarta City ). Journal of Midwifery and Reproduction, 4(2), 41-50. https://doi.org/10.35747/jmr.v4i2.691.

Pakpahan, R., \& Fitriani, Y. (2020). Analisa Pemafaatan Teknologi Informasi Dalam Pemeblajaran Jarak Jauh Di Tengah Pandemi Virus Corona Covid-19. JISAMAR (Journal of Information System, Applied, Management, Accounting and Researh), 4(2), 30-36. http://journal.stmikjayakarta.ac.id/index.php/jisamar/article/view/181.

Putria, H. (2020). Analisis Proses Pembelajaran Dalam Jaringan (DARING) Masa Pandemi COVID-19 pada Guru Sekolah Dasar. Jurnal BASICEDU, 4(4), 861-872. https://doi.org/10.31004/basicedu.v4i4.460.

Rohimah, N. (2018). Pengaruh Penyuluhan Keluarga Berencana terhadap Peningkatan Pengetahuan tentang Keluarga Sakinah. Irsyad: Jurnal Bimbingan, Penyuluhan, Konseling, Dan Psikoterapi Islam, 6(3), 263-284. https://doi.org/10.15575/irsyad.v6i3.900.

Setiawan, E. (2019). Efforts To Increase Speaking0skills In Front Of The Class With Role Playing Techniques In Group Counseling Service For Students In Class VII B SMP Negeri 21 Banjarmasin. Jurnal Pelayanan Bimbingan Dan Konseling, 2(2), 155-161. http://ppjp.ulm.ac.id/journals/index.php/jpbk/article/view/3410/2610.

Sudarti, K., \& Prasetyaningtyas, P. (2011). Peningkatan Minat Dan Keputusan Berpartisipasi Akseptor Kb. JDM (Jurnal Dinamika Manajemen), 2(2), 130-138. https://doi.org/10.15294/jdm.v2i2.2477.

Sukarni, Sudirman, \& Yusuf, H. (2020). Hubungan Konseling Keluarga Berencana dan Pengetahuan Ibu Dengan Pemilihan Metode Kontrasepsi Di Wilayah Kerja Puskesmas Mamboro. Jurnal Kolaboratif Sains, 1(1), 339-348. https://doi.org/10.31934/jom.v1i1.1182.

Winarni, L. M., Judistiani, T. D., Ruslami, R., Husin, F., Sutedja, E., \& Herawati, D. M. D. (2014). Penggunaan Model CIPP dalam Evaluasi Kurikulum Inti Pendidikan D-III Kebidanan. Indonesian Journal of Education and Midwifery Care, 1(1). https://doi.org/10.24198/ijemc.v1i1.77. 